\title{
Defective cell-cell adhesion in hyh mutant mice: a pathogenic mechanism underlying cerebral ventricular surface disruption and hydrocephalus?

\author{
Luis Federico Bátiz*, César A González, Alexander Ortloff, Cristian Oliver, \\ Sara Rodríguez and Esteban M Rodríguez
}

Address: Instituto de Antomía, Histología y Patología, Universidad Austral de Chile, Valdivia, Chile

Email: Luis Federico Bátiz* - federicobatiz@uach.cl

* Corresponding author

from 52nd Annual Meeting of the Society for Research into Hydrocephalus and Spina Bifida

Providence, RI, USA. II-I4 June 2008

Published: 3 February 2009

Cerebrospinal Fluid Research 2009, 6(Suppl I):S24 doi:10.I 186/I743-8454-6-SI-S24

This abstract is available from: http://www.cerebrospinalfluidresearch.com/content/6/SI/S24

(c) 2009 Bátiz et al; licensee BioMed Central Ltd.

\section{Background}

The hyh mutant mice develop a severe, progressive hydrocephalus accompanied by disruption of the cerebral ventricular surface and distortion of the brain architecture. Although a point mutation (M105I) in alpha-SNAP protein has been identified as responsible of the hyh phenotype, many of the pathogenic mechanisms underlying this process remain unknown. Considering that alpha-SNAP is involved in the vesicular traffic of proteins to plasma membrane, we proposed that hyh mutation could result in a failure in cell-cell adhesion during brain development. To test this hypothesis, we decided to investigate (i) the presence of alpha-SNAP and N-cadherin in different regions of the brain, (ii) the ultrastructure of adherens junctions at ventricular surface, and (iii) the physiology of cell-cell adhesion in neural progenitor cells (NPCs) cultures.

\section{Materials and methods}

Mice of the hyh strain (B6C3Fe-a/a-hyh/J) were used in this study. Brain samples of non-hydrocephalic (wild type (WT) or heterozygous) and hydrocephalic (mutant homozygous) mice from embryonic day 10.5 to postnatal day 30 were studied by western blot, immunocytochemistry and transmission electron microscopy. NPCs derived from embryonic cerebral cortices were cultured to give rise to clonal aggregates of undifferentiated neural precursors, called neurospheres. Floating neurospheres were subjected to different treatments including calcium switch (EGTA treatment) and $\mathrm{N}$-cadherin functional blocking assays using competitive peptides.

\section{Results}

(1) alpha-SNAP and N-cadherin were preferentially expressed at the ventricular lining; (2) alpha-SNAP expression followed a temporal pattern that matched that of ventricular lining disruption; (3) loss of adherens junctions and changes in $\mathrm{N}$-cadherin immunocytochemical pattern were observed at the ventricular surface of mutant animals, prior to its disruption; (4) neurospheres derived from hyh mutant mice were dramatically disorganized when treated with EGTA or N-cadherin blocking peptide, (5) aggregation properties were diminished in NPCs derived from hyh mice when compared to WT NPCs; (6) neuropathological features previously related to defective cell-cell adhesion at the ventricular surface (neuroepithelial cells protruding into the ventricular lumen and ependymal rosettes formation) were clearly distinguished in hyh mutant brains.

\section{Conclusion}

Taking together, our results suggest that alpha-SNAP mutation causes defective cell-cell adhesion at the ventricular surface which, in turn, leads to ventricular lining 
disruption, abnormal cortical development and hydrocephalus.

Publish with Bio Med Central and every scientist can read your work free of charge

"BioMed Central will be the most significant development for disseminating the results of biomedical research in our lifetime. " Sir Paul Nurse, Cancer Research UK

Your research papers will be:

- available free of charge to the entire biomedical community

- peer reviewed and published immediately upon acceptance

- cited in PubMed and archived on PubMed Central

- yours - you keep the copyright

Submit your manuscript here:

http://www.biomedcentral.com/info/publishing_adv.asp 